\title{
Correction to: Bottom mixed layer oxygen dynamics in the Celtic Sea
}

\author{
Tom Hull (i) - Martin Johnson • Naomi Greenwood · Jan Kaiser
}

Published online: 7 July 2020

(C) The Author(s) 2020

\section{Correction to: Biogeochemistry}

https://doi.org/10.1007/s10533-020-00662-x

The initial online publication contained several typesetting errors. The original article has been corrected.

Open Access This article is licensed under a Creative Commons Attribution 4.0 International License, which permits use, sharing, adaptation, distribution and reproduction in any medium or format, as long as you give appropriate credit to the original author(s) and the source, provide a link to the
Creative Commons licence, and indicate if changes were made. The images or other third party material in this article are included in the article's Creative Commons licence, unless indicated otherwise in a credit line to the material. If material is not included in the article's Creative Commons licence and your intended use is not permitted by statutory regulation or exceeds the permitted use, you will need to obtain permission directly from the copyright holder. To view a copy of this licence, visit http://creativecommons.org/licenses/by/4.0/.

Publisher's Note Springer Nature remains neutral with regard to jurisdictional claims in published maps and institutional affiliations.

The original article can be found online at https://doi.org/10. 1007/s10533-020-00662-x.

T. Hull $(\bowtie) \cdot$ N. Greenwood

Centre for Environment, Fisheries and Aquaculture

Science, Lowestoft, UK

e-mail: tom.hull@cefas.co.uk

T. Hull · M. Johnson · N. Greenwood · J. Kaiser Centre for Ocean and Atmospheric Science, School of Environmental Sciences, University of East Anglia, Norwich, UK 